\title{
Teaching for Earth Resilience: A Strategy for Increased Diversity and Equity
}

\begin{abstract}
Sarah K. Fortner, Geology Dept. and Environmental Science Program, Wittenberg University, Springfield, Ohio 45501, USA; Cathryn A. Manduca, Science Education Resource Center, Carleton College, Northfield, Minnesota 55057, USA; Laura A. Guertin, Dept. of Earth Science, Penn State Brandywine, Media, Pennsylvania 19063, USA; David W. Szymanski, Dept. of Natural and Applied Sciences, Bentley University, Waltham, Massachusetts 02452, USA; and Joshua Villalobos, El Paso Community College, El Paso, Texas 79998, USA
\end{abstract}

\section{INTRODUCTION}

The geosciences fall behind all other reporting science, technology, engineering, and math (STEM) fields in graduation rates of underrepresented minorities (URM) (Wilson, 2017). Improving diversity and inclusion in our profession is important not only to meet the demand of our workforce, it is critical for improving community and policy outcomes. For this reason, we suggest that geoscience educators adopt a focus on earth resilience and the approaches it requires. Earth resilience is the ability to equitably, justly, and sustainably manage, plan, and adapt to resource challenges at local to global scales. The work of earth resilience professionals (e.g., disaster planning, environmental justice) calls for more than disciplinary skills and habits; it relies on empowering the talents of underrepresented and marginalized communities and networking to improve outcomes. Drawing from these strategies, earth educators might support more diverse and inclusive geosciences by (1) connecting with URM students through culturally and societally relevant curriculum that builds the disciplinary and civic skills and habits needed for social change, and (2) creating networks that expand entry points, mentoring, representation, and career preparation (Fig. 1). We describe examples of strategies that begin to empower URM students and call for greater investment on their behalf.

\section{CURRICULUM FOR SOCIAL \\ CHANGE}

Equitably and justly addressing challenges like climate change, natural disasters, air quality, water quality, challenges that disproportionately impact underrepresented and marginalized populations, calls for a curriculum that goes beyond our traditional view of core competencies (e.g., Mosher et al., 2014). Outcomes in communities will be determined by how well our graduates can navigate codes, laws, and power structures, as well as their ability to work across disciplines, cultures, and identities. Those working on earth-resilience challenges (e.g., disaster response) navigate these challenges by working in and with the communities and engaging them in all aspects of project development (e.g., NRC, 2012). Outcomes improve when barriers to participation are reduced and efforts incorporate the interests and strategies that resonant with communities (NRC, 2012). Education that engages students in communities to address resilience priorities provides a mechanism for developing these skills.

Within our courses, active, societally and culturally relevant engagement provides students with the skills and habits needed for both geoscience and social change. Active learning (e.g., low stakes practice of skills and habits) reduces disproportionately high URM student failure rates in STEM disciplines (Freeman et al., 2014). The historically black colleges and universities geosciences working group has also identified a need to incorporate culturally (e.g., Pan-African) and societally relevant content that appeals to diverse students (Archer et al., 2019). More than $50 \%$ of URM STEM students surveyed rated working for social change as an "essential" or "very important" professional goal, significantly more than

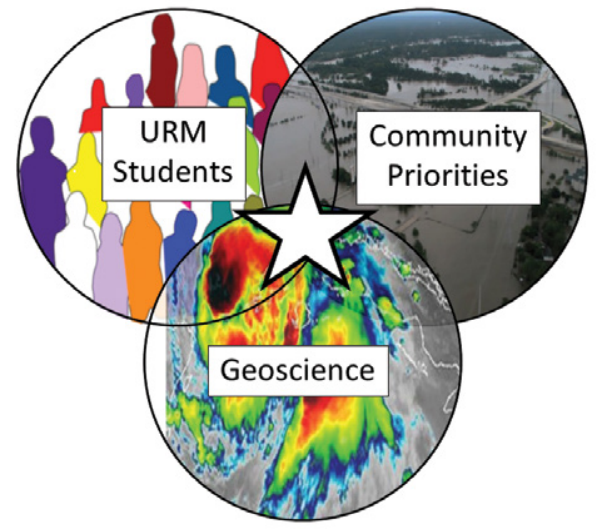

Figure 1. An earth-resilience approach to geoscience education features an intentional focus on improving underrepresented minority (URM) student and community outcomes. Within our courses, active and culturally situated learning co-delivers disciplinary and civic skills and habits needed to improve community outcomes. Networks expand entryways, mentors, representation, resources, and opportunities for URM students.

non-URM students (Garibay, 2015). The InTeGrate Project (https://serc.carleton .edu/integrate/) offers insight into how to join the skills and habits identified by professionals with the skills and habits needed for social change (Gosselin et al., 2019). Openly available course modules engage students in evaluating the reliability of information (e.g., Carbon, Climate and Energy Resources), analyzing justice issues (e.g., Environmental Justice and Freshwater Resources), mirroring the community participatory process (e.g., Food as the Foundation for Healthy Communities), and connecting earth challenges to governance and ethics (e.g., Lead in the Environment). 
NETWORKS TO BUILD CAPACITY

Networks with broader communities are sorely needed to improve geoscience student outcomes. Undergraduates especially need relevant work experience. Yet most geoscience graduates have only completed one research experience, and fewer than $60 \%$ have had an internship (Wilson et al., 2017). Access to opportunities is especially important at two-year colleges, which serve the greatest percentage of URM students but often face greater barriers (e.g., time, resources). Building and capitalizing on networks can improve pathways into the geosciences; expand perspectives, representation, or mentoring opportunities; and link learning about Earth to community concerns and employment opportunities. Programs that engage $\mathrm{K}-12$ schools, employers, community groups, alumni, or other programs expand interest, mentoring, representation, and access to research, internship, and geotechnical opportunities.

One example that expands URM student opportunities using networks is NSF-funded Service Learning Activities Targeting the Earth Science, which engages students in service-learning opportunities around local water issues. The program unites El Paso Community College, The University of Texas at El Paso, and El Paso Water Utilities in developing activities that attract new geoscience majors and actively work with communities on priority issues (Doser, 2018). Another example is the EarthConnections project. Developed through pilots in three communities, EarthConnections emphasizes co-creation with the community, coupling of classroom learning and community application, connecting learning opportunities for students of different ages, and mentoring and signposting that help students define an educational path aligned with their interests (Manduca et al., 2018).

The next step toward earth resilience is to move from a few examples to a widespread effort to connect geoscience learning and resilience both locally and globally. This approach will help make our discipline relevant and reciprocal with diverse communities, diversify our science, and strengthen the capacity for living successfully and equitably on Earth.

\section{REFERENCES CITED}

Archer, R.S., Davis, F., Ebanks, S.C., and Gragg, R.D.S., 2019, HBCUs broadening participation in geosciences (a journey through InTeGrate), in Gosselin, D.C., Egger, A.E., and Taber, J.J., eds., Interdisciplinary Teaching about Earth and the Environment for a Sustainable Future: Berlin, Springer, Cham, p. 361-378, https:// doi.org/10.1007/978-3-030-03273-9_17.

Doser, D., 2018, SLATES: A collaborative service learning program for two-year and four-year college students in the El Paso, Texas, region: Geological Society of America Abstracts with Programs, v. 50, no. 6, https://doi.org/10.1130/abs/2018AM-319102.

Freeman, S., Eddy, S.L., McDonough, M., Smith, M.K., Okoroafor, N., Jordt, H., and Wenderoth, M.P., 2014, Active learning increases student performance in science, engineering, and mathematics: Proceedings of the National Academy of Sciences of the United States of America, v. 111, no. 23, p. 8410-8415, https://doi.org/10.1073/pnas.1319030111.
Garibay, J.C., 2015, STEM students' social agency and views on working for social change: Are STEM disciplines developing socially and civically responsible students?: Journal of Research in Science Teaching, v. 52, no. 5, p. 610-632, https://doi.org/ $10.1002 /$ tea. 21203 .

Gosselin, D.C., Manduca, C.A., Bralower, T., and Egger, A.E., 2019, Preparing students to address societally relevant challenges in the geosciences: The InTeGrate approach, in Gosselin, D.C., Egger, A.E., and Taber, J.J., eds., Interdisciplinary Teaching about Earth and the Environment for a Sustainable Future: Berlin, Springer, p. 3-23, https://doi.org/ 10.1007/978-3-030-03273-9_1.

Manduca, C., Charlevoix, D., Taber, J., Pandya, R., and Nagle, B., 2018, EarthConnections Alliance: Strengthening and diversifying the geoscience workforce and the geoscientific capacity of communities: Kansas City, Earth Educators Rendezvous, https://serc.carleton .edu/earth_rendezvous/2018/program/talks/ mondayB/202242.html (accessed Aug. 2018).

Mosher, S., Bralower, T., Huntoon, J., Lea, P., McConnell, D., Miller, K., Ryan, J.G., Summa, L., Villalobos, J., and White, L., 2014, Future of Undergraduate Geoscience Education: Summary Report for Summit on Future of Undergraduate Geoscience Education: School of Geosciences Faculty and Staff Publications 1127, https://scholarcommons.usf.edu/ geo_facpub/1127.

National Research Council (NRC), 2012, Disaster Resilience: A National Imperative: Washington, D.C., The National Academies Press, https://doi.org/10.17226/13457.

Wilson, C., 2017, Status of recent geoscience graduates: American Geosciences Institute, https://www.americangeosciences.org/sites/ default/files/ExitSurvey_2017_Online _041018.pdf.

Manuscript Received 20 SePt. 2018 REVISED MANUSCRIPT RECEIVED 2 May 2019 MANUSCRIPT ACCEPTED 5 MAY 2019 